\title{
Seasonal variations of gonadotropins in the pars distalis male Viscacha pituitary. Effect of chronic melatonin treatment
}

\author{
V. Filippa, A. Penissi, ${ }^{1}$ F. Mohamed
}

Cátedra de Histología y Embriología, Facultad de Química, Bioquímica y Farmacia, Universidad Nacional

de San Luis. Av. Ejército de los AndesSan Luis, Argentina; ${ }^{1}$ Instituto de Histología y Embriología (IHEM), Universidad Nacional de Cuyo, (5500) Mendoza, Argentina; Consejo Nacional de Investigaciones

Científicas y Técnicas (CONICET), Argentina

(C)2005, European Journal of Histochemistry

The gonadotropes, LH and FSH cells, were immunohistochemically identified in the pituitary pars distalis of the adult male viscacha (Lagostomus maximus maximus) using specific antibodies against hLH, and hFSH, with the streptavidinbiotin-peroxidase complex. The distribution, size and percentage immunopositive area of these cells were analyzed by image analysis in viscachas captured during the annual reproductive cycle and after the chronic administration of melatonin. The $\mathrm{LH}$, and FSH $\beta$ cells showed seasonal changes in the distribution, size and percentage immunopositive area. The LH $\beta$ cells were found widely distributed throughout the pars distalis during the reproductive period, and they were found in the ventro-medial region in the pars distalis during the gonadal regression and gonadal recovery periods. The LH $\beta$ cells reached the largest size and immunopositive area during the reproductive period and the smallest size and immunopositive area during the gonadal regression period. The FSH $\beta$ cells were found in the ventro-medial region during reproductive and gonadal regression periods. The FSH $\beta$ cells were found widely distributed throughout the pars distalis during the gonadal recovery period when they showed the maximum percentage immunopositive area. A decrease in the size of $\mathrm{LH}$, and $\mathrm{FSH} \beta$ cells was observed after the chronic administration of melatonin. Moreover, it produces a decrease in the immunopositive area occupied by the LH, cells but not in the immunopositive area occupied by the FSH $\beta$ cells. Our results show great activity of $\mathrm{LH} \beta$ and FSH $\beta$ cells in different moments of the annual reproductive cycle demonstrating that these cells are not secrete in parallel. Moreover, melatonin acts differentially on the activity of the gonadotrope cells.

Key words: viscacha, LH, FSH, reproductive cycle, melatonin, immunohistochemistry.

Correspondence: Dr. Veronica Filippa

Cátedra de Histología y Embriología, Facultad de Química, Bioquímica y Farmacia, Universidad Nacional de San Luis, Av. Ejército de los Andes 950-2 ${ }^{\circ}$ Piso, San Luis, Argentina Fax: 54.2652.422644/430224.

E-mail: vpfilipp@unsl.edu.ar

Paper accepted on April 26, 2005

European Journal of Histochemistry

2005; vol. 49 issue 3 (Jul-Sep): 291-300
V ariations in the gonadotrope cells depending on the moment of the reproductive cycle, age and sex of the animal have been described for various species. Seasonal changes in the gonadotropes during the annual reproductive cycle have been reported in fishes (Shimizu et al., 2003), amphibians (Pinelli et al., 1996), reptiles (Desantis et al., 2000) and mammals (Eagle and Tortonese, 2000; Kuwahara et al., 2000). Many mammals use the photoperiod as the main cue for timing their annual cycles of reproduction. The pineal melatonin rhythm is an internal signal that represents day length and that is capable of regulating a variety of seasonal variations in physiology and behavior (Goldman, 1999). The pituitary gonadotropins ( $F S H$ and LH) control the reproductive processes. The synthesis and secretion of these hormones are regulated by GnRH (Krsmanovic et al., 2000), GnIH (Ubuka et al., 2005), gonadal steroids and peptidic factors inhibin, activin and follistatin (Fingscheidt et al., 1998; Kawakami et al., 2002). Seasonal changes in the size of the GnRH hypothalamic neurons were reported, suggesting that the synthesis and secretion of $\mathrm{GnRH}$ are promoted and increased during the reproductive season in comparison with the non-reproductive season (Kuwahara et al., 2000). Moreover, it has been reported that the GnRH gene expression and secretion can be controlled by melatonin (Roy and Belsham, 2002). On the other hand, it has been recently reported that melatonin derived from pineal pituitary and eyes acts as a potent gonadotropin-inhibitory hormone $(\mathrm{GnIH})$-inducing factor in birds (Ubuka et al., 2005). It has also been demonstrated that the chronic administration of melatonin produced a decrease in the concentration of plasmatic testosterone in horses (Argo et al., 1991), inhibition of gonadotropin liberation and gonadal regression in siberian hamsters (Goldman, 2000) and golden hamsters (Shiotani et al., 1985). Therefore, the reproductive activity in these species 
is stimulated by long days. On the contrary, the treatment with melatonin in sheep stimulated the liberation of gonadotropins and the testicular function, showing that the reproductive activity is stimulated by short days (Lincoln, 2000).

The viscacha (Lagostomus maximus maximus) is a rodent mammal of nocturnal habits that lives in underground caves in semiarid zones in the center of Argentina. One of the most important signals that participate in the regulation of the annual reproductive cycle in viscacha is the environmental photoperiod. Our previous investigations have demonstrated that the adult male in its natural habitat exhibits a reproductive cycle characterized by three periods: (1) Reproductive period, period of gonadal activity, during the long days of summer and early autumn; (2) Gonadal regression period, during the short days of winter; and (3) Progressive recovery period of the gonadal activity, during the early spring months. That is, in the adult male viscacha the short photoperiod inhibits the reproductive processes, and the long photoperiod promotes the development of the sexual activity (Dominguez et al., 1987; Fuentes et al., 1991, 1993; Muñoz et al., 1997, 2001; Pelzer et al., 1999; Mohamed et al., 2000).

Considering the viscacha to be an animal of seasonal reproduction and taking into account these previous investigations, the aim of the work was to study the relation between the natural photoperiod and the activity of the gonadotrope cells. Morphometrical parameters of these cells along the reproductive annual cycle were analized. In addition, the effect of the chronic administration of melatonin on the gonadotrope cells was studied. The analysis of the LH and FSH cells and their integration with the pineal hypothalamo pituitary-gonadal axis are essential to understand the reproductive processes in the Lagostomus maximus maximus.

\section{Materials and Methods}

Twelve adult male viscachas weighting 5,000 to $7,000 \mathrm{~g}$ were captured in their habitat near San Luis, Argentina ( $33^{\circ} 20^{\prime}$ south latitude, $760 \mathrm{~m}$ altitude) during the most representative months of the reproductive cycle, over a 1-year period: FebruaryMarch (reproductive period in summer-earlyautumn) 4 animals; August (gonadal regression period in winter) 4 animals; September-October (gonadal recovery period in spring) 4 animals.
In San Luis, in summer there is up $14 \mathrm{hr}$ light daily (14L:10D) with an average temperature of $25^{\circ} \mathrm{C}$. In winter, the light phase decreased to $10 \mathrm{hr}$ (10L:14D) and the average temperature, to $10^{\circ} \mathrm{C}$. In spring, the light phase increased to $12 \mathrm{hr}$ (12L:12D) and the average temperature, to $15^{\circ} \mathrm{C}$.

The animals were anesthetized with Nembutal (pentobarbital) and killed by decapitation. The brain was rapidly exposed and the pituitary gland was excised, sagittally sectioned and processed for light microscopy, fixed in Bouin's fluid, embedded in paraffin and serially sectioned in the horizontal plane. Administration of melatonin: eight adult male viscachas captured during the month of February (summer) were used. The rodents were kept in isolated boxes with free access to water and food at $20 \pm 2{ }^{\circ} \mathrm{C}$. They were maintained under a 14L:10D photoperiod. The experimental group received two daily subcutaneous injections of melatonin (Sigma, $100 \mathrm{mg} / \mathrm{Kg}$ body weight in oil solution) at 09:00 hr y 17:00 hr, during 9 weeks. The control group received only the diluent.

\section{Immunohistochemical techniques}

Serial sagittal sections ( $5 \mu \mathrm{m}$ thick) were cut and carried through xylene and graded alcohols to water. Slides were incubated for $20 \mathrm{~min}$ in a solution of $3 \% \mathrm{H}_{2} \mathrm{O}_{2}$ in water to inhibit endogenous peroxidases activity. Then they were rinsed with distilled water and phosphate buffered saline (PBS, $0.01 \mathrm{M}, \mathrm{pH}$ 7.4). Non specific binding sites for immunoglobulins were blocked by incubation for 15 min with $0.25 \%$ casein in PBS and rised with distilled water and PBS. Sections were then incubated overnight in a moist chamber at $4^{\circ} \mathrm{C}$ with the following primary antisera developed against pituitary hormones: anti-human (h) FSH $\beta, 1: 200$, and antihFSH $\beta$, 1:100 (BioGenex, San Ramon, USA). After they were rinsed with PBS for 10 min, the immunohistochemical visualization was carried out using the Super Sensitive Ready-to-Use Immunostaining Kit (BioGenex, San Ramon, USA) at $20^{\circ} \mathrm{C}$. The Biotin-Streptavidin Amplified (B-SA) system was used as follows. Sections were incubated for 30 min with diluted biotinylated anti-mouse IgG, and after being washed in PBS, they were incubated for 30 min with horseradish peroxidaseconjugated streptavidin, and finally washed in PBS. The reaction site was revealed by $100 \mu \mathrm{L}$ 3.3'diaminobenzidine-tetrahydrochoride (DAB) cromogen solution in $2.5 \mathrm{~mL}$ PBS $50 \mu \mathrm{L} \mathrm{H}_{2} \mathrm{O}_{2}$ sub- 
Table 1. Seasonal variations of the distribution, size and percentage immunopositive area of anti-hLH $\beta$ serum positive cells of adult male viscachas (Lagostomus maximus maximus).

\begin{tabular}{lccc}
\hline \hline & $\begin{array}{c}\text { Reproductive } \\
\text { period }(4)\end{array}$ & $\begin{array}{c}\text { Gonadal regression } \\
\text { period }(4)\end{array}$ & $\begin{array}{c}\text { Gonadal recovery } \\
\text { period }(4)\end{array}$ \\
\hline Distribution & $\begin{array}{c}\text { throughout pars } \\
\text { distalis }\end{array}$ & ventro-medial & ventro-medial \\
$\begin{array}{l}\text { Major cellular } \\
\text { diameter }(\mu \mathrm{m})\end{array}$ & $17.20( \pm 0.09)^{\mathrm{a}}$ & $15.72( \pm 0.25)^{\mathrm{b}}$ & $16.77( \pm 0.23)$ \\
$\begin{array}{l}\text { Minor cellular } \\
\text { diameter }(\mu \mathrm{m})\end{array}$ & $11.50( \pm 0.04)^{\mathrm{a}}$ & $10.76( \pm 0.11)^{\mathrm{b}}$ & $11.53( \pm 0.35)$ \\
$\begin{array}{l}\text { \% Immunopositive } \\
\text { area }\end{array}$ & $4.51 \pm 0.23^{\mathrm{c}}$ & $2.48 \pm 0.24^{\mathrm{d}}$ & $2.28 \pm 0.18^{\mathrm{e}}$ \\
\hline
\end{tabular}

Means \pm SEM. Number of animals for period in parentheses. a vs. $b: p<0.05 ; c$ vs. $d-e$ : $p<0.001$

strate solution. The slides were counterstained with Hematoxylin for $1 \mathrm{~min}$, dehydrated and mounted. In all cases, two controls for specificity of the primary antibodies were made: (1) omission of primary antibody, and (2) absorption of primary antibody with homologous antigen.

\section{Morphometric study}

Computer-assisted image analysis system was used to measure the immunopositive area of $\mathrm{LH}$ and FSH cells from hemi-pituitaries at different levels in the three periods of the reproductive cycle and after treatment of melatonin. The system consisted of a Nikon Optiphot-2 binocular microscope (magnification, X 400), interfaced with a host computer, image processing, and recording system. The images were captured by a Panasonic GP- KR222 camera and processed with Image Pro Plus 5.0 software under control of a Pentium IV computer. The software allowed the following processes: image acquisition, automatic analogous adjust, thresholding, background subtraction, distance calibration, area measuring, and diskette data logging. The image was displayed on a color monitor, and the immunopositive areas were measured with the image analysis system. Before counting, a standard area of $34009 \mu \mathrm{m}^{2}$ was defined on the monitor, and distance calibration was performed using a slide with a micrometric scale for microscopy (Rechert, Austria). Fields not entirely occupied by the tissue were not analyzed. The light microscope images of 80 fields per section ( 4 serial sections per pituitary gland) were evaluated. Four pituitary glands for each reproductive period were used. Finally 1280 measurements were performed for period of the reproductive cycle. Four pituitary glands for both groups of the administration of melatonin (experi- mental and control) were used, and 1280 measurements for group were performed. The results were expressed as percentage of the standard area and presented as means \pm SEM. The major and minor diameters of each cell type were measured for 200 cells of each period and groups of the administration of melatonin. These cells had a visible nucleus and they were immunostained with its antiserum for observation under $40 \times$ objective. Means and standard errors were calculated for all data sets. All data of the three periods of the reproductive cycle were evaluated using one-way analysis of variance (ANOVA) followed by Tukey-Kramer Multiple Comparison Test. Differences between experimental and control groups were evaluated using Student's t-test. A probability of less than 0.05 was assumed to be significant.

\section{Results}

The cells immunoreactive to anti-h-LH $\beta$ serum exhibited seasonal variations in the distribution, size and percentage area occupied all through the annual reproductive cycle (Table 1). In the three periods, the LH $\beta$ cells were found along the sinusoidal surface as well as in the interior cell cords and near the follicular structures. They were scattered or grouped in small clusters (Figure $1 d$ ). The $\mathrm{LH} \beta$ cells were found widely distributed throughout the pars distalis during the reproductive period (summer-early autumn) (Figure la). In this period, the $L H \beta$ cells were oval in shape with an eccentric nucleus (Figure le) and they reached the largest cellular diameters $(p<0.05)$ and percentage immunopositive area $(p<0.001)$ in relation to the values found in gonadal regression period (winter). The LH $\beta$ cells were mainly found in the ventromedial region during the gonadal regression period (Figure $1 b$ ). In this period, the LH $\beta$ cells showed a significant decrease in the cellular diameters and the smallest percentage area occupied. During the gonadal recovery period (spring), the LH $\beta$ cells were found in the ventro-medial region and in a smaller proportion in the dorsal region (Figure $1 \mathrm{c}$ ). The cellular diameters and the percentage immunopositive area did not show significant variations $(p>0.05$ ) in relation to the values found in the gonadal regression period (Table 1 ).

The treatment with melatonin showed variations in the distribution, size and percentage area occupied by the LH $\beta$ cells between the experimental and 

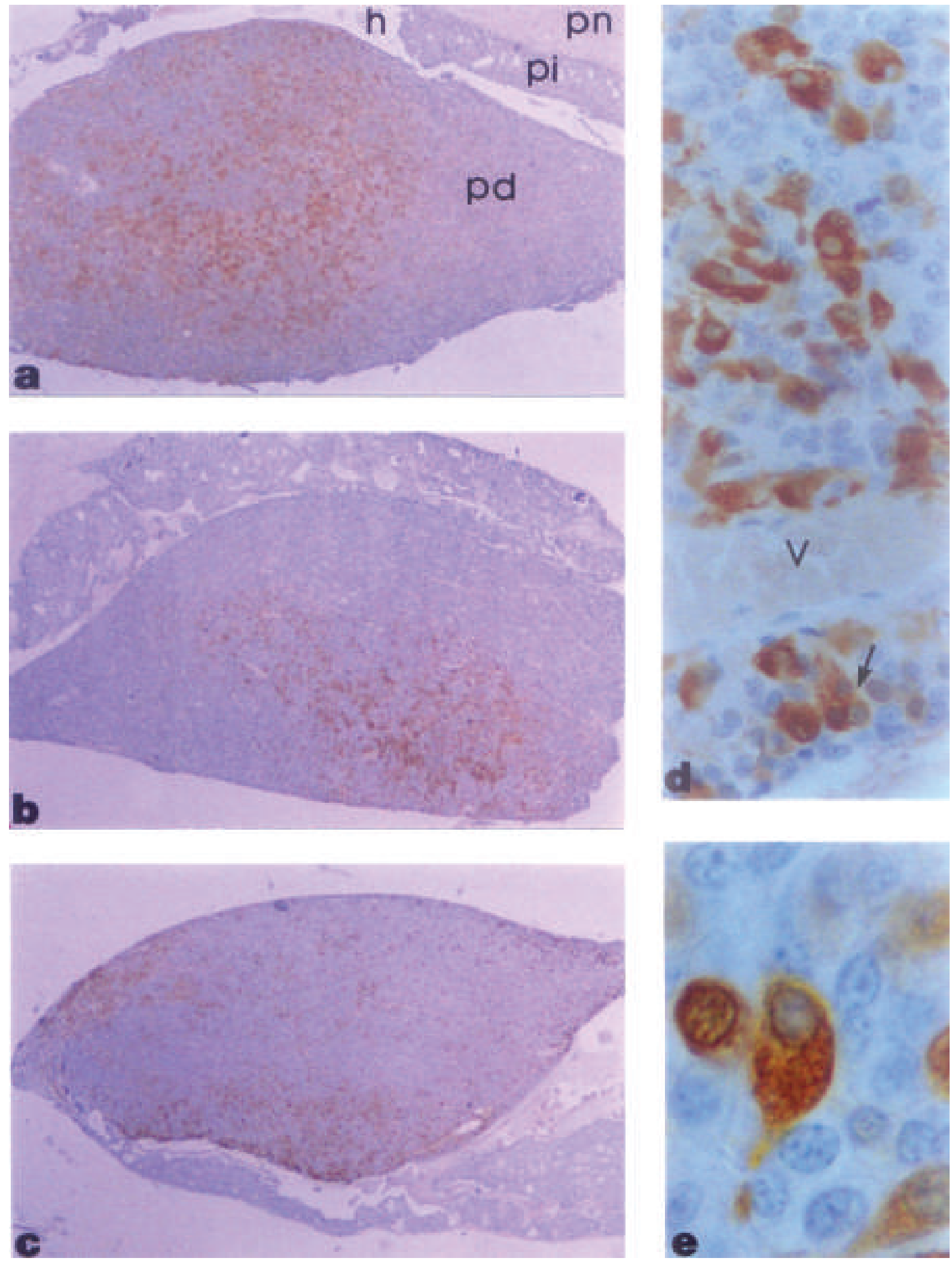

Figure 1 a-e. Light micrographs of pituitary pars distalis immunostained with anti-hLHb. a) Section of gland during the reproductive period (summer-early autumn). pd: pars distalis; pi: pars intermedia; pn: pars nervosa; $h$ : Rathke's pouch. x 20. b) Frontal section of gland during the gonadal regression period (winter). x 20. c) Gonadal recovery period (spring). $x$ 20. d) LH $\beta$ cells along the surface of blood vessels $(v)$ and grouped in small clusters (arrow), during the reproductive period. $x$ 400. e) LH $\beta$ cells oval in shape during the reproductive period. $x 1000$. 
Table 2. Effect of melatonin on the distribution, size and percentage immunopositive area of the anti-hLH $\beta$ serum positive cells of adult male viscachas (Lagostomus maximus maximus).

\begin{tabular}{lcc}
\hline & Control group (4) & Experimental group (4) \\
\hline Distribution & throughout pars distalis & ventro-medial \\
Major cellular diameter $(\mu \mathrm{m})$ & $18.51( \pm 0.28)^{\mathrm{a}}$ & $16.13( \pm 0.20)^{\mathrm{b}}$ \\
Minor cellular diameter $(\mu \mathrm{m})$ & $12.97( \pm 0.25)^{\mathrm{a}}$ & $11.09( \pm 0.06)^{\mathrm{b}}$ \\
\%Immunopositive area & $2.04 \pm 0.22^{\mathrm{c}}$ & $0.57 \pm 0.14^{\mathrm{d}}$
\end{tabular}

Means \pm SEM. Number of animals for group in parentheses. a vs. b: $p<0.05 ; c$ vs. $d: p<0.01$.

the control groups. Moreover, a significant decrease of the cellular diameters $(p<0.05)$ and of the percentage immunopositive area $(p<0.01)$ were observed in animals treated with melatonin (Table 2). These results were similar to those found in the summer-early autumn vs. winter seasonal study.

The cells immunoreactive to anti-h-FSH, serum showed seasonal variations in the distribution, size and percentage area occupied (Table 3). In every period of the annual reproductive cycle, these cells were localized in clusters along the surface of blood vessels, forming cellular cords, lying in close proximity to follicular structures and occasionally isolated. They were oval in shape, and the nucleus was usually located opposite the sinusoidal end of the cells (Figure $2 \mathrm{~d}-\mathrm{f}$ ). In the reproductive period (summer-early autumn), the FSH, cells were localized mainly in the ventro-medial region of pars distalis (Figure 2a). In this period, the percentage area occupied by the FSH, cells was the smallest of the three periods. The FSH, cells were localized in the ventro-medial region of the pars distalis during gonadal regression (winter) (Figure $2 b$ ). These cells showed a significant decrease in the cellular diameters $(p<0.05)$, but the percentage immunopositive area did not show significant changes in relation to

Table 3. Seasonal variations of the distribution, size and percentage immunopositive area of anti-hFSH $\beta$ serum positive cells of adult male viscachas (Lagostomus maximus maximus).

\begin{tabular}{|c|c|c|c|}
\hline & $\begin{array}{l}\text { Reproductive } \\
\text { period (4) }\end{array}$ & $\begin{array}{c}\text { Gonadal regression } \\
\text { period (4) }\end{array}$ & $\begin{array}{l}\text { Gonadal recovery } \\
\text { period (4) }\end{array}$ \\
\hline Distribution & ventro-medial & ventro-medial & throughout pars distalis \\
\hline $\begin{array}{l}\text { Major cellular } \\
\text { diameter }(\mu \mathrm{m})\end{array}$ & $17.58( \pm 0.36)^{a}$ & $14.32( \pm 0.34)^{b}$ & $17.35( \pm 0.34)^{c}$ \\
\hline $\begin{array}{l}\text { Minor cellular } \\
\text { diameter }(\mu \mathrm{m})\end{array}$ & $11.61( \pm 0.24)^{a}$ & $9.29( \pm 0.26)^{b}$ & $12.00( \pm 0.23)^{c}$ \\
\hline $\begin{array}{l}\% \text { Immunopositive } \\
\text { area }\end{array}$ & $0.41 \pm 0.06^{d}$ & $1.02 \pm 0.11^{\mathrm{e}}$ & $5.39 \pm 0.25^{f}$ \\
\hline
\end{tabular}

area

Means \pm SEM. Number of animals for period in parentheses. $b$ vs. $a-c: p<0.05 ; f v s . d$ e: $p<0.001$.
Table 4. Effect of melatonin on the distribution, size and percentage immunopositive area of the anti-hFSH $\beta$ serum positive cells of adult male viscachas (Lagostomus maximus maximus).

\begin{tabular}{lcc}
\hline \hline & Control group (4) & Experimental group (4) \\
\hline Distribution & ventro-medial & ventro-medial \\
Major cellular diameter $(\mu \mathrm{m})$ & $17.02( \pm 0.20)^{\mathrm{a}}$ & $15.45( \pm 0.17)^{\mathrm{b}}$ \\
Minor cellular diameter $(\mu \mathrm{m})$ & $11.23( \pm 0.02)^{\mathrm{a}}$ & $10.50( \pm 0.15)^{\mathrm{b}}$ \\
$\%$ Immunopositive area & $1.78 \pm 0.28$ & $1.64 \pm 0.31$ \\
\hline
\end{tabular}

Means \pm SEM. Number of animals for group in parentheses. a vs. $b: p<0.05$.

the previous period. In the gonadal recovery period (spring), the FSH, cells were found widely distributed in the pars distalis (Figure 2c). The cellular diameters and the percentage area occupied increased significantly $(p<0.05$ and $p<0.001$, respectively) in this period of the reproductive cycle (Table 3). The melatonin treatment demonstrated that the distribution in the parenchyma of the pars distalis did not vary in the experimental group in relation to the control group. A significant decrease $(p<0.05)$ was observed in the cellular diameters of animals treated with melatonin, but the percentage immunopositive area did not show significant changes ( $p>0.05$ ) (Table 4$)$. These results were similar to those found in the summer-early autumn vs. winter seasonal study.

\section{Discussion}

Adult male viscachas in their natural habitat exhibit a short gonadal regression period during winter characterized by a reduction of the testicular weight and of the diameter of the seminiferous tubules (Fuentes et al., 1991). In addition, hypotrophic Leydig cells (Muñoz et al., 1997), seminiferous epithelium with Sertoli cells, spermatogonia and a few primary spermatocytes (Muñoz et al., 2001) and minimum concentrations of serum testosterone (Fuentes et al., 1993) were described. On the other hand, the secretory ability of the pineal gland was increased (Dominguez et al., 1987) and maximum levels of melatonin in blood were determined (Fuentes et al., 2003). The testicular activity is slowly recovered during spring and it reaches its maximum during summer and early autumn in the reproductive period.

The present immunohistochemical study of the LH $\beta$ and FSH, cells of the pars distalis of Lagostomus maximus maximus during the annual reproductive cycle and after the chronic administration of melatonin demonstrates that: 1 ) the 

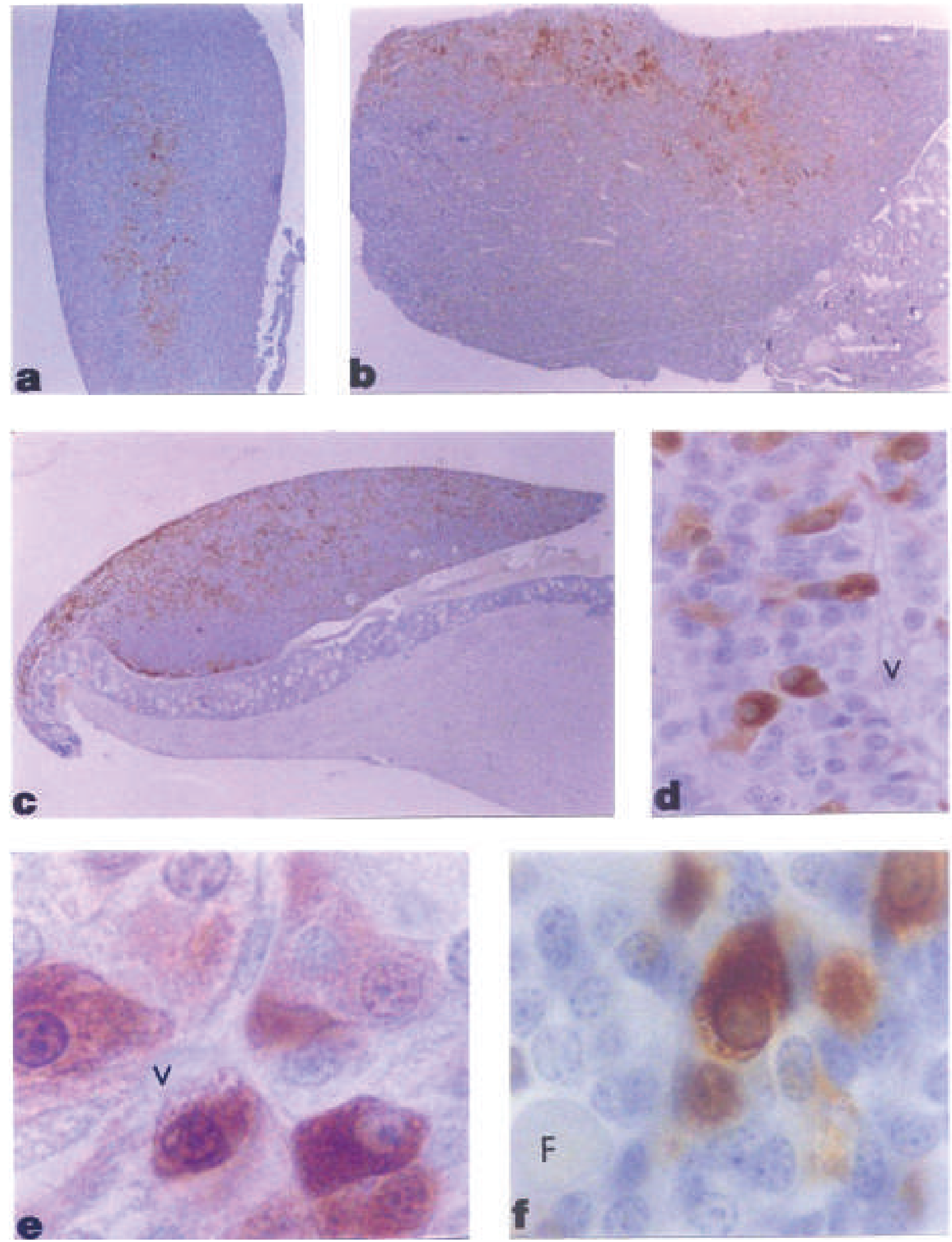

Figure 2 a-f. Light micrographs of pituitary pars distalis immunostained with anti-hFSH $\beta$. a) Section of gland during the reproductive period. $x$ 20. b) Gonadal regression period. $x 20$. c) Gonadal recovery period. $x$ 20. d) FSH, cells isolated during the reproductive period. v: blood vessels. $x$ 400. e) FSH, cells oval in shape and along the surface of blood vessels (v) during the gonadal recovery period. $x$ 1000. f) FSH, cells in proximity to follicular structure (F). x 1000. 
LH $\beta$ and FSH, cells exhibit seasonal variations in their distribution, size and percentage area occupied during the annual reproductive cycle, 2) the size and percentage area occupied by the LH $\beta$ cells reach their maximum values in the reproductive period (summer-early autumn) and they are widely distributed throughout in pars distalis, 3) the administration of melatonin causes a decrease of the cellular size and of the percentage area occupied by the $L H \beta$ cells, 4) the size and percentage immunopositive area occupied by the FSH $\beta$ cells reach their maximum values in the gonadal recovery period (spring) and they are widely distributed throughout in pars distalis, and 5) the administration of melatonin causes a decrease of the cellular size but not of the percentage immunopositive area occupied by the FSH $\beta$ cells. In mice (Kuwahara et al., 2000), bats (Kawamoto et al., 2000) and ruin lizards (Desantis et al., 2000) have observed a decrease in number and size of cells $\mathrm{LH}$ in the nonbreeding season suggesting a decrease in the $\mathrm{LH}$ hormone synthesis. Variations in the secretion of $\mathrm{LH}$ as a function of the gonadal activity were described during the annual reproductive cycle in the mink (Jallageas et al., 1994). These variations show an increase in the pituitary activity in the reproductive season and a clear decrease of the activity during the testicular regression stage. Sosnowski et al., (2000) have reported that GnRH neuropeptide stimulates the expression of the genes of the LH subunits and the novo synthesis of this hormone. Other studies have shown that melatonin can inhibit the transcriptional activity of the genes in the gonadotropes and the liberation of $\mathrm{LH}$ through the decrease of intracellular messengers (Vanecek et al., 1998; Slanar et al., 2000). Moreover, melatonin is involved in the neuroendocrine control of the reproductive physiology through its direct action on the GnRH neurons, controlling the expression of the GnRH gene through a transcription factor (Gillespie et al., 2004).

In viscacha, the numerous LH $\beta$ cells in all pars distalis reach the largest cellular size and percentage area occupied during the reproductive period (summer-early autumn), demonstrating a great cellular activity of synthesis and liberation of $\mathrm{LH}$ necessary to maintain testicular steroidogenesis and spermatogenesis. Maximum concentrations of serum LH and testosterone as well as hypertrophic Leydig cells in the testicles were found during this period (Fuentes et al., 1991; García-Assef, 1996;
Muñoz et al., 1997). During the gonadal regression period the $\mathrm{LH} \beta$ cells in the pituitary pars distalis are small and occupy the smallest percentage area, these results of the seasonal study correlate with those obtained after the chronic administration of melatonin. In both studies, a decrease in the size of the $\mathrm{LH} \beta$ cells and in the percentage immunopositive area were observed, demonstrating that melatonin inhibits the cellular activity of the $\mathrm{LH} \beta$ cells, probably acting on the hypothalamic factors. We concluded that the pineal melatonin could be the mediator of central photoperiodic control of the $\mathrm{LH} \beta$ cells. Kuwahara et al., (2000) have described a decrease in the number and size of the FSH, cells in the pars distalis of the japanese wood mouse, arrest of spermatogenesis and a decrease in the concentration of serum testosterone during the nonreproductive season. Desantis et al., (2000) have reported that the size and percentage area occupied by FSH, cells in ruin lizards have an annual pattern with two distinct peaks, suggesting that the increase in FSH production is related to the increase in spermatogenic period.

In rats, cell size and numerical variations of gonadotropes have been reported in relation to physiological and experimental condition (Tougard and Tixier-Vidal, 1988), but there hasn't been any information about change in shape. Also Shimizu et al., (2003) have examined the seasonal variations in the gonadotrope cells of the mummichog, demonstrating that both cells ( $\mathrm{LH}$ and FSH) were abundant in the spawning period (spring and early summer). However, the relative quantities of both cell types were different during the other seasons, and the $\mathrm{FSH}$, cells predominated during the pre-spawning period, suggesting that both gonadotropins play important, though different, roles in reproduction.

Moreover, the degree to which either the hypothalamus or pituitary contribute to the effect of testosterone has not been defined thoroughly. Studies in different experimental models and different species have led to conflicting results. Dubey et al., (1987) showed that neither testosterone nor oestradiol had any negative feedback action on the pituitary in monkeys in vivo. Studies in men confirmed this suppressive effect of testosterone on $\mathrm{LH}$ and $\mathrm{FSH}$ at the pituitary site (Bagatell et al., 1994). Kumar and Low (1995) claim that testosterone suppresses the increase of mRNA of FSH,. aateos et al., (2002) showed that high circulating steroid levels seem to exert a different action on 
gonadotropin secretion, inhibiting FSH while stimulating LH synthesis.

Fingscheidt et al., (1998) have reported in cellular cultures that $\mathrm{GnRH}$ antagonists inhibit the increase of serum $\mathrm{FSH}$, and that $\mathrm{GnRH}$ causes an increase in the liberation of FSH three times lower than the one caused in the liberation of LH. These data suggest that FSH secretion is only partially dependent on the liberation of GnRH. The fact that melatonin is involved in the control of $\mathrm{GnRH}$ gene expression and secretion has been demonstrated in works carried out in cellular cultures (Roy and Belsham, 2002; Gillespie et al., 2004). Ubuka et al., (2005) have observed that the effects of the melatonin implants on GnIH mRNA and GnIH peptide were in the same direction as those resulting from changes in endogenous melatonin. They concluded that melatonin acts as a potent $\mathrm{GnIH}$-inducing factor, thus influencing gonadal activity.

In viscacha, the FSH, cells of pituitary pars distalis are small and do not occupy a large percentage area during the testicular regression period (winter). The FSH, cells are numerous in all pars distalis during the gonadal recovery period (spring). They reach the largest cellular size and percentage area occupied. This demostrates that the FSH, cells play an important role during spring when the recovery of the testicular activity of adult male viscachas starts. These findings suggest that these cells are synthesizing great quantities of the FSH hormone that stimulates Sertoli cells to initiate the spermatogenic processes. The ability of the Sertoli cells to synthesize, pack and secrete cellular products necessary in the spermatogenesis depends on the local hormone levels (Muñoz et al., 2001).

On the other hand, the maximum levels of serum testosterone were found during the reproductive period of the viscacha (Fuentes et al., 1993). A decrease in the percentage area occupied by the $\mathrm{FSH}$, cells was observed in the pars distalis, suggesting that testosterone acts on these cells, whether directly or indirectly, regulating their activity. In viscacha, the results of the seasonal study correlated with those obtained after chronic administration of melatonin. In those studies, a decrease in the size of the FSH, cells was observed but there was not decrease in the percentage immunopositive area. This demonstrates that melatonin acts differentially on the activity of the gonadotrope cells.

In conclusion, the differences found in the gonadotrope cells of viscacha in the three periods of the annual reproductive cycle suggest different roles of FSH and LH in the testicular steroidogenesis and spermatogenesis. Our results show great activity of LH and FSH cells in different moments of the annual reproductive cycle, demonstrating that these cells do not secrete in parallel. These variations probably result from complex regulation mechanisms that involve the action of the melatonin hormone, GnRH, GnIH and testosterone. Moreover, as it was described in other species, activin, inhibin, follistatin and other peptides would be involved in complex autocrine and paracrine mechanisms that regulate the gonadotrope cells activity (Besecke et al., 1996; Fingscheidt et al., 1998). Further experiments with the Lagostomus maximus maximus might be necessary to examine the relation between the photoperiod-melatonin and the various factors involved in the control of the gonadotrope cells that are responsible for the differential pattern of secretion and storing of pituitary FSH and LH.

\section{Acknowldgements}

We wish to thank Mrs A. Bernardi, Mr. J. Arroyuelo and Mr. N. Perez for their technical participation. This work was supported by Proyect 22/Q303, CyT, UNSL.

\section{References}

Argo CM, Cox JE, Gray JL. Effect of oral melatonin treatment on the seasonal physiology of pony stallions. J Reprod Fertil 1991; Suppl 44:115-25.

Bagatell CJ, Dahl KD, Bremner WJ. The direct pituitary effect of testosterone to inhibit gonadotropin secretion in men is partially mediated by aromatization to estradiol. J Androl 1994; 15:15-21.

Besecke LM, Guendner MJ, Schneyer AL, Bauer-Dantoin AC, Jameson $J \mathrm{~L}$, Weiss J. Gonadotropin-releasing hormone regulates folliclestimulating hormone-, gene expression through an activin/follistatin autocrine or paracrine loop. Endocrinol 1996; 137: 3667-73.

Desantis S, Labate M, Corriero A, Labate GM, De Metrio G. Immunohistochemical evidence of seasonal changes of gonadotropes in male ruin lizard (Podarcis sicula campestris De Betta ). Eur J Histochem 2000; 44:385-95.

Dominguez S, Piezzi RS, Scardapane L, Guzmán J. A light and electron microscopic study of the pineal gland of the viscacha (Lagostomus maximus maximus). J Pineal Res 1987; 4:211-19.

Dubey AK, Zeleznik AJ, Plant TM. In the rhesus monkey (Macaca mulatta), the negative feedback regulation of follicle-stimulating hormone secretion by an action of testicular hormone directly at the level of the anterior pituitary gland cannot be accounted for by either testosterone or estradiol. Endocrinol 1987; 121:2229-37.

Eagle RC, Tortonese DJ. Characterization and distribution of gonadotrophs in the pars distalis and pars tuberalis of the equine pituitary gland during the estrous cycle and seasonal anestrus. Biol Reprod 2000; 63: 826-32.

Fingscheidt $U$, Weinbauer GF, Fehm $\mathrm{HL}$, Nieschlag E. Regulation of gonadotrophin secretion by inhibin, testosterone and gonadotrophinreleasing hormone in pituitary cell cultures of male monkeys. J Endocrinol 1998; 159:103-10. 
Fuentes L, Caravaca N, Pelzer L, Scardapane L, Piezzi RS, Guzmán JA. Seasonal variations in the testis and epididymis of the viscacha (Lagostomus maximus maximus). Biol Reprod 1991; 45: 93-97.

Fuentes L, Calvo JC, Charreau E, Guzmán J. Seasonal variations in testicular LH, FSH, and Prl receptors; in vitro testosterone production; and serum testosterone concentration in adult male viscacha (Lagostomus maximus maximus). Gen Comp Endocrinol 1993; 90:133-41.

Fuentes L, Møller M, Muñoz E, Calderón C, Pelzer L. Seasonal variations in the expression of the mRNA encoding,1-Adrenoceptor and AA-NAT enzyme, and in the AA-NAT activity in the pineal gland of vizcacha (Lagostomus maximus maximus)- Correlation with serum melatonin. Biol Rhythm Res 2003; 34(2):193-206.

Garcia Aseff S. Tesis Doctoral: "Estudio bioquímico e histológico de los efectos de litio sobre el eje hipófiso-gonadal de vizcacha adulta. Aspectos farmacocinéticos". . Biblioteca Central UNSL. 1996.

Gillespie JM, Roy D, Cui H, Belsham DD. Repression of gonadotropinreleasing hormone $(\mathrm{GnRH})$ gene expression by melatonin may involve transcription factors COUP-TFI and C/EBP beta binding at the GnRH enhancer. Neuroendocrinol 2004; 79(2):63-72.

Goldman BD. The circadian timing system and reproduction in mammals. Steroids 1999; 64:679-85.

Goldman BD. The siberian hamster as a model for study of the mammalian photoperiodic mechanism. In: James Olcese, eds. Melatonin after Four Decades. Kluwer Academic/ Plenum Publishers, New York, 2000, pp 155-64.

Jallageas M, Mas N, Boissin J, Maurel D, Ixart G. Seasonal variations of pulsatile luteinizing hormone release in the mink (Mustela vison) Comp Biochem Physiol C Pharmacol Toxicol Endocrinol 1994; 109:9-20.

Kawakami S, Fujii Y, Okada Y, Winters SJ. Paracrine regulation of FSH by follistatin in folliculostellate cell-enriched primate pituitary cell cultures. Endocrinol 2002; 143(6):2250-58.

Kawamoto K, Tanaka S, Hayashi T. Secretory activity of gonadotropin and the responsiveness of gonadotrophs to gonadotropin-releasing hormone during the annual reproductive cycle of male bats, Rhinolophus ferrumequinum: analysis by cell immunoblot assay. $J$ Exp Zool 2000; 287(3):213-24.

Krsmanovic LZ, Martinez-Fuentes AJ, Arora KK, Mores N, Tomic M Stojilkovic SS, Catt KJ. Local regulation of gonadotroph function by pituitary gonadotropin-releasing hormone. Endocrinol 2000; 141:1187-95.

Kumar TR, Low MJ. Hormonal regulation of human follicle-stimulating hormone-beta subunit gene expression: GnRH stimulation and $\mathrm{GnRH}$-independent androgen inhibition. Neuroendocrinol 1995; 61:628-37.

Kuwahara S, Mizukami T, Omura M, Hagihara M, Iinuma $Y$, Shimizu $Y$, Tamada H, Tsukamoto $Y$, N ishida T, Sasaki F. Seasonal changes in the hypothalamo-pituitary-testes axis of the Japanese wood mouse (Apodemus speciosus). Anat Rec 2000; 260:366-72.

Lincoln G. Melatonin modulation of prolactin and gonadotrophin secretion. Systems Ancient and Modern. In: James Olcese, eds. Melatonin after Four Decades. Kluwer Academic/ Plenum Publishers, New York, 2000, pp 137-53.
Mateos J, Mañanos E, Carrillo M, Zanuy S. Regulation of follicle-stimulating hormone (FSH) and luteinizing hormone ( $\mathrm{LH}$ ) gene expression by gonadotropin-releasing hormone $(\mathrm{GnRH})$ and sexual steroids in the Mediterranean Sea bass. Comp Biochem Physiol 2002; 132:75-86.

Mohamed F, Fogal T, Dominguez S, Scardapane L, Guzmán J, Piezzi RS. Colloid in the pituitary pars distalis of viscacha (Lagostomus maximus maximus): ultrastructure and occurrence in relation to season, sex, and growth. Anat Rec 2000; 258:252-61.

Muñoz E, Fogal T, Dominguez S, Scardapane L, Guzmán J, Piezzi RS. Seasonal changes of the Leydig cells of viscacha (Lagostomus maximus maximus). A light and electron microscopy study. Tissue \& Cell 1997; 29(1):119-28.

Muñoz EM, Fogal T, Dominguez S, Scardapane L, Piezzi RS. Ultrastructural and morphometric study of the Sertoli cell of the viscacha (Lagostomus maximus maximus) during the annual reproductive cycle. Anat Rec 2001; 262:176-85.

Pelzer LE, Calderón CP, Guzmán J. Changes in weight and hydroxyindole-0-methyltransferase activity of pineal gland of the plains viscacha (Lagostomus maximus maximus). Mastozool Neotrop 1999; 6:31-8.

Pinelli C, Fiorentino M, D'Aniello B, Tanaka S, Rastogi R. Immunohistochemical demonstration of FSH and $\mathrm{LH}$ in the pituitary of the developing frog, Rana esculenta. Gen Comp Endocrinol 1996; 104:189-96.

Roy D, Belsham DD. Melatonin receptor activation regulates $\mathrm{GnRH}$ gene expression and secretion in GT1-7 GnRH neurons. Signal transduction mechanisms. J Biol Chem 2002; 277(1):251-58.

Shimizu A, Tanaka H, Kagawa H. Immunocytochemical applications of specific antisera raised against synthetic fragment peptides of mummichog GtH subunits: examining seasonal variations of gonadotrophs (FSH cells and LH cells) in the mummichog and applications to other acanthopterygian fishes. Gen Comp Endocrinol 2003; 132:35-45.

Shiotani Y, Cho HJ, Shiosaka S, Tasaka K, Miyake A, Aono T. Changes in the pineal gland, LH-RH neuron system and pituitary-gonadal axis in golden hamsters under artificial winter conditions. Biomed Res 1985; 6(5):297-305.

Slanar 0, Pelisek V, Vanecek J. Melatonin inhibits pituitary adenylyl cyclase-activating polypeptide-induced increase of cyclic AMP accumulation and $[\mathrm{Ca} 2+] \mathrm{i}$ in cultured cells of neonatal rat pituitary. Neurochem Int 2000; 36(3):213-19.

Sosnowski $\mathrm{R}$, Mellon $\mathrm{PL}$, Lawson MA. Activation of translation in pituitary gonadotrope cells by gonadotropin-releasing hormone. Mol Endocrinol 2000; 14:1811-19.

Tougard C, Tixier-Vidal A.: Lactotropes and gonadotropes. In: Knobil E., Neill J. et al. (eds.), The Physiology of reproduction, Raven Press, Ltd, New York, 1988, pp. 1306-33.

Ubuka T, Bentley GE, Ukena K, Wingfield JC and Tsutsui K. Melatonin induces the expression of gonadotropin-inhibitory hormone in the avian brain. Proc Natl Acad Sci 2005, 102(8):3053-57.

Vanecek J. Melatonin inhibits release of luteinizing hormone $(\mathrm{LH})$ via decrease of [Ca2+]i and cyclic AMP. Physiol Res 1998; 47(5):32935. 
V. Filippa et al. 